\title{
Gazette
}

\section{Annual Business Meeting}

\section{Rules for the Annual Business Meeting and Association Elections}

The following rules proposed by the Association's Rules Committee were approved by the Council at its April 8 meeting.

\section{Annual Business Meeting: Attendance and Participation}

The right "to attend and to participate in the Annual Business Meeting of the Association" is constitutionally accorded "all members, upon payment of such registration fees as the Council may approve." (Art. III, sec. 7).

1.1. Attendance at the Annual Business Meeting shall be restricted to members of the Association who have paid the approved registration fee and to registered representatives of the media. Participation in the Annual Business Meeting shall be restricted to members of the Association who have paid the approved registration fee.

1.2. Members upon registration shall be issued nontransferable badges readily distinguishable from badges issued nonmember registrants and representatives of the media.

1.3. The Registration Desk shall be open (in addition to the normal registration hours) at least during the first hour of the Annual Business Meeting or, if the Meeting is held in separate time periods, during the first hour of each such meeting.

1.4. A prospective candidate for elective office of the Association must become a dues-paying member upon filing for office.

1.5. One hundred members are necessary for a quorum (as required by Article VII, Section 1 of the Constitution).

\section{Conduct of the Annual Business Meeting}

2.1. The agenda of each Annual Business Meeting will be: nomination and election of officers, Constitutional amendments, resolutions, and other business.

2.2. The Council shall prepare and publish a full agenda for each Annual
Business Meeting, including the texts of all proposed amendments and resolutions, with statements of the Council's recommendations on each, such full agenda to be made available to members at the beginning of the Annual Business Meeting.

2.3. On any proposed constitutional amendment or resolution, the first signer of a proposed amendment or resolution (or signer's designee) shall be recognized as the first speaker on that amendment or resolution and shall be allotted a maximum of five minutes.

2.4. In accordance with the Council's constitutional authority to make recommendations on all proposed amendments and resolutions (Art. VIII; Art. IX, sec. 1), the second speaker on any proposed constitutional amendment or resolution not sponsored by the Council shall be a member designated by the Council to present its views. That member shall also be allotted a maximum of five minutes.

2.5. Each speaker after the first two speakers specified in Rules 2.3 and 2.4 shall be allotted a maximum of three minutes. The President shall recognize alternately proponents and opponents of the proposed amendment or resolution being considered, so long as members of each group seek recognition, subject to the previous question being ordered.

2.6. The proposer of any amendment offered from the floor to a proposed amendment or resolution shall be recognized as the first speaker on that floor amendment, and shall be allotted a maximum of three minutes. Any amendment offered from the floor to a proposed amendment or resolution shall require a second. Each subsequent speaker on that floor amendment shall be allotted a maximum of three minutes. The President shall recognize alternately proponents and opponents of the floor amendment being considered, so long as members of each group seek recognition, subject to the previous question being ordered.

2.7 . Debate on any proposed amendment or resolution or amendment from the floor shall close and a vote be taken when a member moves the previous question and a majority supports the motion.

2.8. Any amendment that fails to gain support of 40 percent of those members present and voting shall be defeated; any amendment supported by at least 40 percent of those members present and voting shall be referred to the full membership by mail ballot. (Art. IX, sec. 2). Whenever one-third or more of those present and voting at the Annual Business Meeting vote in support of any resolution, the question shall be submitted to the entire membership in a mailed secret ballot under conditions prescribed by the Council and shall be determined by a majority of those voting by mail on the question. (Art. VIII).

2.9. In accordance with the mail ballot requirements specified in Sec. 2.8 , a motion to table, postpone, or defer an amendment must be supported by at least 60 percent of the members present and voting to pass. A motion to table, postpone, or defer a resolution must be supported by at least two-thirds of the members present and voting to pass. If an amendment has been tabled, it may be lifted from the table if at least onethird of the members present and voting cast votes to do so.

2.10 . If the total of the minority vote and abstentions shall equal or exceed the plurality vote but the minority vote shall fall below the percentage required for a mail ballot, a motion shall be entertained to present the issue to the membership on a mail ballot. No debate shall be permitted on such a motion which shall be decided by a simple majority of the votes actually cast.

2.11. In order that the members may have the materials available to study prior to the Annual Meeting, reports of officers and committees of the Association shall be published and distributed to members prior to the Annual Meeting. Copies of such reports shall be received by the Executive Director no later than May 25.

2.12. Normally no oral reports of officers and committees of the Association shall be presented at the Annual Business Meeting, except for the report of the Chairman of the Nominating Committee, a Budget summary by the Treasurer, and the certification of candidates by the Elections Committee. However, an opportunity for members to question and discuss the written reports shall be provided.

2.13. Except as otherwise provided in the Constitution, By-Laws, and these Rules of Procedure, the Annual 
Business Meeting shall be governed by the rules set forth in the most recent edition of Sarah Corbin Roberts (ed.), Robert's Rules of Order (Glenview, Ill.: Scott, Foresman and Co.).

\section{Proposal of Resolutions and Constitutional Amendments}

The present Constitution provides, "Amendments to the Constitution may be proposed by the Council or by fifty (50) members of the Association. The Council shall transmit all proposed amendments to the next Annual Business Meeting and may make recommendations on those amendments originating outside the Council."' (Art. IX, sec. 1).

"The Council shall have any proposed amendment printed in an official publication of the Association prior to the next Annual Business Meeting. The Council shall then place the proposed amendment on the agenda of the Business Meeting. The Business Meeting may accept or reject the proposed amendment with or without further amendments to it. Within thirty (30) days the Executive Director shall submit amendments supported by at least forty percent $(40 \%)$ of those members present and voting at the Annual Business Meeting to the entire membership for vote by mail ballot. Ballots must be returned within thirty $(30)$ days to be counted. A proposed amendment will be ratified if approved by a majority of those voting. An amendment shall take effect immediately upon ratification unless the amendment itself provides otherwise." (Art. IX, sec. 2).

A resolution may be proposed by the Council under its general responsibilities and constitutional mandate to "give its recommendations upon all questions (except the election of officers) to be presented to the Annual Business Meeting."' (Art. VII, sec. 2). The Constitution contemplates the initiation of resolutions by others than the Council but is silent upon the specifics of such initiation. (Art. VIII). Accordingly, a resolution may be proposed by a single member of the Association.

The Constitution requires that every resolution and proposed constitutional amendment (unless initiated by the Council itself) shall be referred to the Council for consideration and recommendation before submission to the Association at its Annual Business Meeting, and that every thus-referred resolution and proposed amendment, regardless of Council recommendation on it, shall be submitted by the Council to the Association for action at its An- nual Business Meeting. (Arts. VIII and IX)

To implement these Constitutional requirements, the Rules Committee proposes the following rules:

3.1. No resolution or proposed constitutional amendment shall be considered by the Council or transmitted to the Annual Business Meeting unless it bears the personal signatures of the fifty proposers in the case of a constitutional amendment or at least one proposer in the case of a resolution. In the former case any of the proposers may authorize their identification as proposers by a signed communication to the Executive Director specifically indicating the proposed amendment they support.

3.2. In publishing a proposed constitutional amendment, only the constitutionally required number of signatures in the sequence originally presented will normally be listed.

3.3. The Constitution stipulates that "the Council shall have any proposed [constitutional] amendment printed in an official publication of the Association prior to the next Annual Business Meeting." (Art. IX, sec. 2). To implement this requirement, all proposed amendments to the Constitution shall be published in the September issue of $P S$. The texts and the signatures or authorizations of the sponsors of any such amendment shall therefore be received by the Executive Director no later than May 25.

3.4. The Constitution stipulates that "all resolutions shall be referred to the Council for its recommendations before submission of the vote of the Association at its Annual Business Meeting." (Art. VIII). The By-Laws require that all material to be considered by the Council must be in the hands of the Council members fourteen days prior to the Council meeting. To implement these provisions, all resolutions (except those proposed by the Council) shall be received by the Executive Director no later than August 3. However, to encourage full discussion and consideration by the membership as well as the Council, proposers of resolutions are urged to deliver them to the Executive Director by May 25 so that they may be published in the September issue of $P S$.

\section{Nominations and Elections of Officers}

To implement the procedures for making nominations for elected officers and for conducting contested elections by mail ballot for the entire member- ship (Art. V), the following rules shall be followed:

4.1. Each notification of proposed additional nominations (whether for a slate of nominees for all offices, for a set of nominees for certain offices, or for a nominee for one office) shall be valid only if it carries the personal signatures of at least ten members on the official forms which shall be made available by the Association. There shall also be available candidate consent forms as provided below. Such documents shall also include a signed assent to the candidacy by the proposed nominee or an attestation by the election agent that the nominee has agreed to the candidacy. In the event of attestation by the agent, the candidacy shall be deemed valid only upon receipt of a letter mailed to the Chairperson of the Elections Committee in care of the Association headquarters and postmarked within 7 days of the close of the Annual Meeting.

4.2. The Chairperson of the Elections Committee shall receive at the Association's Washington offices, or after Monday, August 28, 1995 at the Association's Annual Meeting office in the headquarters hotel, all nominations and any individual certifications by members of authority for the inclusion of their names on the original nominating document. In accordance with Article $\mathrm{V}$, section 2 of the Constitution, all such nominations and certifications must be received at least 24 hours before the session of the Annual Business Meeting at which the nomination and election of officers is scheduled to take place.

4.3. The official nominating document shall identify the individual who will act as Election Agent for the candidate or candidates. The Agent shall be responsible for the requirements for valid nomination and the responsibilities listed in section 4.1.

4.4. Well in advance of the Annual Business Meeting the President shall appoint three members of the Council to serve as the Committee on Elections, and shall designate one member as Chairperson. Notification to the Chairperson of the Committee on Elections shall be deemed to be the notification to the Secretary as required by Article V of the Constitution. The Committee on Elections shall implement the Constitution's requirements and the Council's rules in the preparation and mailing of the ballots and the information supplements to be mailed with the ballots both for election of officers, and for referenda on proposed amendments to the Constitution, or resolutions. In so doing, it acts as Agent 
of the Council which retains primary responsibility for conduct of elections.

4.5. At the session of the Annual Business Meeting at which nominations are made, the Chairperson of the Elections Committee shall certify the candidacies properly qualified. The Chairperson of the Elections Committee shall also separately list candidates qualified pending receipt of written consent. The Chairperson of the Elections Committee shall also announce the names of the designated Election Agents. A complete list of such certifications shall also be given or sent to each Election Agent and candidate and posted at the official Association Meeting office in the headquarters hotel.

4.6. A request to withdraw from nomination previously assented to by the candidate must be made by the candidate by registered mail postmarked within 7 days of the end of the Annual Meeting and sent to the Chairperson of the Elections Committee in care of the Association.

The election agent may inform the Chairperson of the Elections Committee in care of the Association if a substitution has been agreed to by six or more members of the nominating group. If such notification is received within 14 days of the close of the Business Meeting, the substitute nomination shall appear upon the ballot. Official assent by the candidate must be received within 15 days of the close of the Business Meeting. In the case of withdrawals of persons named by the Association's Nominating Committee, a substitute nomination will be accepted within a like period if made with a consent of a majority of Committee members.

The Chairperson of the Association's nominating Committee shall be the Election Agent for its nominees.

The Chairperson of the Elections Committee shall mail promptly to all candidates and agents notice of any withdrawals and substitutions of candidates.

4.7. In the event of death, a nominating group shall be permitted to substitute candidates until the time of the printing of the ballot subject to requirements above.

4.8. If two or more persons are nominated for any Association office and a mail ballot is thereby necessitated, each candidate shall be permitted a statement of no more than 100 words for the description of the candidate's professional career and accomplishments and 300 words for a statement of views. Sponsoring groups shall also be permitted a statement of position of no more than 500 words filed by the agent. Can- didates and agents should be encouraged to file such materials with the original nomination petition. Statements will also be accepted if postmarked within 14 days of the close of the Annual Meeting, as will modifications of statements filed earlier. Printer's copy of the ballots shall be circulated by registered mail, return receipt requested, to each candidate and to each election agent. Author changes shall not be made in biographical statements and statements of view of candidates other than correction of typographical errors except at the expense of the author. Changes must be filed by telephone or telegram immediately upon receipt.

4.9. In preparing the ballots, the Committee on Elections shall make sure that:

1) Each office or set of offices is listed on the ballot separately, in an "office-group" ballot form.

2) The candidates in each office group are listed in alphabetical order of their surnames.

3) Under each candidate's name appears:

a) His or her current institutional affiliation; and

b) The names of the persons, group, or groups nominating the candidate.

4.10. The Committee on Elections shall, within the time limits stipulated by the Constitution (Art. V, sec. 1), fix the date on which the ballots will be mailed out and the date by which they must be returned.

4.11. The ballots will be mailed to all members of the Association in good standing as of the close of business on the last working day prior to the mailing date. All ballots to members residing overseas shall be sent by first class mail. An official notice from the national headquarters shall be sent by $\mathrm{Au}$ gust 23 to all whose membership would lapse in the quarter prior to the election giving warning of the last date at which dues can be received guaranteeing eligibility to vote.

In counting the preferential ballots, all the first choices will first be tallied and a winner determined if any nominee has at least fifty (50) percent of the valid votes cast for that office. If no nominee is thus elected, the next step is to eliminate the nominee with the fewest first-preference votes, adding these second preferences to the firstpreference votes cast for each of the other nominees. If any of these other nominees thus receives a total vote (original first preferences plus second preferences from the eliminated nominee's ballots) which is at least fifty (50) percent of the valid votes cast, that nominee shall be elected. If a winner is not then determined (as might be the case when there are more than three nominees), the next step is to eliminate the nominee with the second fewest votes (from original first preferences and any already added second preferences from the first-preference ballots of the previously eliminated nominee) and to count the second preferences marked on this nominee's first-preference ballots and also to count the third preferences marked on those first-preference ballots cast for the nominee first eliminated and which had subsequently been assigned to the now-eliminated nominee on the basis of their secondpreference designations; the votes thus counted are to be added to the firstpreference votes cast for the remaining nominees. If any of these nominees now has a total vote of at least fifty (50) percent of the valid votes cast, that nominee shall be elected. If a winner is not yet determined as a result of this second additional count (as might be the case when there are more than four nominees), a similar procedure shall be followed with respect to the ballots cast for the nominee with the third fewest votes, and, if necessary, with respect to ballots cast for the nominee with the fourth fewest votes and, if necessary, successively with respect to ballots cast for any other nominee ranking as the lowest remaining below the first two. Any questions that might arise about the count, including how to handle ties, shall be resolved according to the procedures followed in elections (as of 1975 and 1977) for the Australian House of Representatives.

Voters are not required to list more than one preference in order to have their vote counted.

In calculating the total number of valid votes cast, valid votes are all of those that have an operative preference on a given count. Those excluded are ballots on which the only preferences listed are for candidates who have already been eliminated.

4.12. The Committee on Elections shall also implement the Council's rules in preparing the mail ballot on referenda and constitutional amendments. The Committee on Elections shall make sure that:

1) The referendum ballot contains, or is accompanied by

a) The complete text of any amendments or constitution, as the case may be, on which the membership is being asked to vote by mail ballot.

b) The complete text of any resolu- 
tion on which the membership is being asked to vote by mail ballot.

2) The referendum ballot or ballots is accompanied by a statement of views including:

a) A statement giving the position of the Council on each proposed amendment or resolution;

b) A statement supporting each proposed amendment or resolution by the principal proposer or his designee; and

c) In those cases where there is manifest opposition to an amendment or resolution, a critical statement by a leading opponent or his designee.

4.13. The Association shall prepare a pamphlet or leaflet which shall include constitutional provisions and rules with respect to elections. It shall make these available to anyone requesting petitions and to groups who nominated candidates the previous year. The Elections Committee may publish a brief statement on election rules in the September issue of $P S$ covering major elements of election practices in the Association.

The Elections Committee may schedule a meeting early in each convention to acquaint members with election procedures.

4.14. Mailing address labels of the APSA may be purchased at cost from the Association by any nominating group.

4.15. Notice of challenges shall be sent to all election agents and candidates.

4.16. Election Agents shall immediately bring any charges of irregularity in the conduct of the election to the Elections Committee which shall investigate such charges. The Committee shall communicate any rulings it may make as a result of such charges, or on other matters affecting the conduct of elections, to all agents and to those movers of resolutions and amendments who may be concerned and to the Council.

4.17. Release of election results shall be the duty of the Elections Committee. It shall promptly inform the Executive Director of the Association, who shall inform all candidates, agents, sponsors, proponents and opponents of issues and may use other appropriate means to inform the membership. In addition, it shall certify results to the President and the Executive Director, and report on such results to the Council. In addition, it shall report on any new rulings that may have been applied.

4.18. Recounts shall be held at the discretion of the Elections Committee or upon reasonable request of a candi- date, agent, proponent or opponent of a resolution or amendment submitted to the Chairperson of the Elections Committee within 30 legal working days after the mailing of the election results. Candidates and Agents involved shall be notified in advance of the time and place of the recount and shall be entitled to be present. Requests for recounts which are denied by the Committee may be appealed to the Council.

4.19. If recounting shall not resolve a tie, the decision shall be made by secret ballot of the certified officers and Council members.

\section{Council Meeting: Observers}

5.1 Meeting of the Council shall be open to attendance by members of the Association.

5.2 Members attending Council meetings under Rule 5.1 are entitled to observe, but not participate in the Council's discussion.

\section{Calendar of Deadlines}

\section{Constitutional Amendments} Thursday, May 25, 5:00 p.m.

All proposed constitutional amendments together with the required fifty signatures shall be filed with the Executive Director.

\section{Officers and Committee Reports Thursday, May 25, 5:00 p.m.}

Reports of officers and committees must be filed with the Executive Director.

\section{Resolutions}

If proposers of resolutions file them with the Executive Director by Thursday, May 25, they will be published in the September $P S$.

\section{Thursday, August 3, 5:00 p.m.}

All proposed resolutions must be filed with the Executive Director.

\section{Membership Notice}

By July 1, an official notice will be sent by the national office to all individuals whose membership will expire in the quarter prior to the election.

\section{Nominations}

If nominations are submitted prior to the Annual Meeting, they should be filed together with the required ten signatures with the Chairperson of the Elections Committee in care of the Association no less than seven days prior to the Annual Meeting. If nominations are filed at the Annual Meeting, they must be filed with the Chairperson of the Elections Committee, at the APSA Office at the convention hotel, according to the Constitution, by at least twenty-four hours prior to the Annual Business Meeting.

\section{1995 Annual Business Meeting}

Saturday, September 2, 5:30 p.m.* Business Meeting Order of Business

I. Nominations of Officers

II. Constitutional Amendments

III. Resolutions

IV. Certification of Nominees by the Election Committee

V. Report of the Treasurer

Sponsors of candidates, resolutions, amendments, and other matters to be attended to at the business meeting are encouraged, but not required, to meet with the presiding officer in the meeting room one-half hour ahead of time to facilitate the flow of business.

\section{APSA Publications List}

*Items marked with an asterisk are available from Customer Services Department, University Microfilms, 300 North Zeeb Road, Ann Arbor, Michigan 48106; (800) 521-0600.

\section{PERIODICALS}

The American Political Science Review. The leading quarterly journal of scholarly articles and book reviews in political science. Included in APSA membership. Back issues: $\$ 20$ per copy, $\$ 80$ per volume.

PS: Political Science \& Politics. Quarterly journal of Association news and lively articles of political analysis. $P S$ is the best single source of information on professional opportunities. Included in APSA membership. Back issues: $\$ 10$ per copy, $\$ 40$ per volume $\$ 15$ for the spring issue which contains the preliminary program).

\footnotetext{
* If necessary, a second Business Meeting will be held at 9:30 a.m. on Sunday, September 13.

An open forum with candidates for APSA offices will be held at 12:15 p.m., Thursday, August 31.
} 